\title{
KARAKTERISASI MORFOLOGI DAUN DAN BUNGA BEBERAPA VARIETAS Hoya coronaria DARI KAWASAN HUTAN KERANGAS AIR ANYIR, BANGKA
}

\author{
Putri Deswanti', Yulian Fakhrurrozi², Sri Rahayu ${ }^{3}$ \\ ${ }^{1}$ Mahasiswa Jurusan Biologi, FPPB, Universitas Bangka Belitung \\ Email: putridswnti@yahoo.co.id \\ ${ }^{2}$ Dosen Jurusan Biologi, FPPB, Universitas Bangka Belitung \\ ${ }^{3}$ Peneliti LIPI, Bogor
}

\begin{abstract}
Hoya coronaria was found in Heath Forest Air Anyir, Bangka in various flower color. Characterization based on morphological characteristics need to clear up the differences between varieties. This research aims to observe morphological variation of six varieties of $H$. coronaria from Heath Forest Air Anyir, Bangka based on morphology vegetative and flower morphology. The descriptive method was used to describe the morphological character. Determination of color based on Munsell Color Chart for Plant Tissues. The six samples of different varieties was used which has different flower color as follow respectively: yellow corolla with pink corona (var1); yellow corolla with white corona (var2); yellow corolla with pink honey line and pink corona (var3); pink corolla with pink honey line and pink corona (var4); pink corolla with pink honey line and white corona (var5); and white corolla with white corona (var6). The six varieties have different characteristic of vegetative and flower part both on qualitative and quantitative measurement. The cluster analyses resulted two sister groups. The first group (group A) consisted of var3, var4, var5, and var6, and the second group (group B) consisted of var1 and var2. Groups A was consisted of two smaller groups, namely group C and group D. Group C consisted of var3, var4 and var5, while group D consisted of var6.
\end{abstract}

Keywords: morphology, variety, characteristics, Hoya coronaria

\section{PENDAHULUAN}

Provinsi Kepulauan Bangka Belitung secara geografis terletak pada $104^{\circ} 50^{\prime}-109^{\circ} 30^{\prime}$ Bujur Timur dan $0^{\circ} 50^{\prime}-4^{\circ} 10^{\prime}$ Lintang Selatan (Kemenhut 2012). Provinsi Kepulauan Bangka Belitung terdiri atas dua pulau besar, yaitu Pulau Bangka dan Pulau Belitung. Berdasarkan Kemenhut (2014) luas kawasan hutan Provinsi Kepulauan Bangka Belitung adalah 192.208 ha, terdiri dari hutan lindung sebesar 31.372 ha dan hutan produksi sebesar 160.836 ha.

Hutan merupakan masyarakat tumbuhan yang didominasi pohon-pohon dan memiliki keadaan lingkungan yang berbeda dengan keadaan di luar hutan (Kusuma et al. 2013). Salah satu tipe hutan di Bangka adalah hutan kerangas. Berdasarkan International Union for Conservation Nature (IUCN), kawasan hutan kerangas dikategorikan memiliki status vulnerable (rawan). Hutan kerangas sebagai suatu komunitas vegetasi yang berkembang pada kondisi tapak terbatas dan sangat mudah terdegradasi (Kissinger et al. 2012). Oleh karena itu, hutan kerangas akan sulit untuk pulih kembali jika mengalami gangguan secara alami maupun dari aktivitas manusia. Hal ini menyebabkan vegetasi yang tumbuh memiliki karakter khusus dan terbatas akibat dari adaptasinya terhadap lingkungan yang terbatas. Salah satu tumbuhan di hutan kerangas Bangka adalah Hoya. 
Hoya merupakan salah satu kelompok tumbuhan epifit dari suku Apocynaceae dan anak suku Asclepiadoideae. Kebanyakan jenisnya merupakan tumbuhan merambat (Goyder 2008; Kleijn \& van Donkelaar 2001 dalam Rahayu 2012). Hoya memiliki keragaman dan variasi warna yang menarik. Mahkota dan korona pada bunga Hoya terdiri dari lima helai yang membentuk formasi seperti bintang (Wanntorp et al. 2006 dalam Rahayu 2012). Hoya diperkirakan terdapat di dunia sekitar 150-200 jenis (Burton 1992 dalam Rahayu 2006), dan sekitar 50-60 jenis diantaranya terdapat di Indonesia (Rahayu 2003). Indonesia diperkirakan memiliki keanekaragaman Hoya paling tinggi (Goyder 1990; Kleijn \& van Donkelaar 2001 dalam Rahayu 2012).

Hoya berpotensi untuk dikembangkan sebagai tanaman hias, karena memiliki bunga yang unik dan indah. Untuk menunjang potensinya sebagai tanaman hias tersebut, perlu diketahui lebih dahulu keanekaragaman varietasnya. Variasi bunga dapat diperoleh secara alami dan buatan, variasi alami biasanya terdapat di alam. Salah satu jenis Hoya ditemukan di kawasan hutan kerangas Air Anyir, Bangka yaitu Hoya coronaria. Kawasan tersebut merupakan salah satu habitat bagi $H$. coronaria di Bangka. Sementara itu, berdasarkan Peraturan Daerah Kabupaten Bangka No. 1 Tahun 2013 kawasan tersebut merupakan kawasan peruntukan industri. Hal ini menyebabkan terjadinya aktivitas pembukaan lahan, selain itu beberapa titik lokasi mengalami kebakaran dan menjadi ancaman bagi keberadaan $H$. coronaria di kawasan tersebut. Populasi $H$. coronaria di Kawasan hutan kerangas Air Anyir Bangka memiliki warna bunga yang bervariasi, sehingga perlu dilakukan karakterisasi untuk mengetahui keanekaragaman varietas $H$. coronaria berdasarkan karakteristik morfologi daun dan bunganya. Data mengenai karakteristik morfologi $H$. coronaria belum pernah dilaporkan. Oleh karena itu, perlu diketahui lebih lanjut berapa banyak variasi $H$. coronaria yang terdapat di lokasi tersebut berdasarkan karakter morfologinya. Pengetahuan mengenai variasi bunga dan morfologi terhadap populasi $H$. coronaria di kawasan hutan kerangas Air Anyir Bangka sangat penting untuk pengembangan tanaman ini sebagai tanaman hias. Selain sebagai dasar untuk pengembangan, pengetahuan tersebut juga dapat berguna untuk strategi koservasi tumbuhan tersebut.

\section{METODE PENELITIAN}

\section{Lokasi dan Waktu}

Pengambilan sampel $H$. coronaria dilakukan di hutan kerangas Air Anyir, Bangka. Sampel dipindahkan dan diadaptasikan di rumah percobaan Jalan Fatmawati Raya, Pangkalpinang. Hal ini dikarenakan kawasan hutan kerangas Air Anyir, Bangka merupakan kawasan peruntukan industri. Alih fungsi kawasan tersebut menyebabkan aktivitas pembukaan lahan yang dilakukan melalui penggusuran dan pembakaran. Pengamatan karakteristik morfologi dilakukan lebih lanjut dirumah percobaan yang diletakkan di bawah naungan. Penelitian ini dilaksanakan pada bulan September-Desember 2015.

\section{Alat dan Bahan}

Alat-alat yang digunakan dalam penelitian ini berupa alat-alat tulis, gunting, jangka sorong, kamera Nikon L320 16,1 mp, penggaris, payung, dan cuter. Bahan yang digunakan adalah buku Munsell Color Chart for Plant Tissues, label gantung, plastik, dan sampel hidup $H$. coronaria berbagai varietas.

\section{Prosedur Penelitian}

\section{Survei Lapangan}

Survei dilakukan untuk memudahkan pengerjaan di lapangan, terlebih dahulu dicari titik lokasi yang akan diambil sampel bunganya untuk diamati lebih lanjut dan dilakukan pemindahan penanaman dirumah percobaan.

\section{Pengamatan Keanekaragaman Morfologi}

Pengamatan keanekaragaman morfologi $H$. coronaria dilakukan melalui karakterisasi daun, batang dan bunga dari masing-masing $H$. coronaria pada berbagai varietas. Varietas bunga yang diamati ada 6 . Pengamatan karakter morfologi di amati dari mulai batang, daun, 
perbungaan, dan bunga, sedangkan buah dan biji tidak dilakukan.

\section{Batang dan Daun}

Pengamatan karakteristik batang $H$. coronaria dilihat dari diameter dan warna batang. Diameter batang diukur dengan jangka sorong pada bagian pangkal, tengah dan ujung batang. Warna batang diamati pada bagian pangkal dan ujung. Pengamatan karakteristik daun dilihat dari susunan daun, tata letak daun, helaian (bangun daun, susunan tulang daun dan bentuk daun) (Tjitrosoepomo 1985), tebal, dan warna daun. Warna daun yang diamati dilakukan pada daun yang terletak di bagian pangkal, tengah dan ujung. Tebal daun diukur dengan jangka sorong dari sisi kanan, tengah dan kiri daun. Dilakukan pengambilan gambar objek tanaman yang diambil dengan jarak konsisten dan pencahayaan yang kontras. Penentuan warna dilakukan dengan color chart dari buku Munsell Color Chart for Plant Tissues (2011).

Perbungaan

Ibu tangkai pada bunga majemuk dapat terjadi percabangan ataupun tidak, ibu tangkai yang bercabang memperlihatkan cara percabangan yang bermacam-macam, berpengaruh pula terhadap urutan mekarnya masing-masing bunga pada suatu bunga majemuk. Dibedakan menjadi 3 golongan: bunga majemuk tak berbatas (racemosa), bunga majemuk berbatas (cymosa) dan bunga majemuk campuran (mixta).

Bunga

Pengamatan karateristik bunga Hoya dilihat dari warna dan bentuk bagian bunga seperti tandan bunga, tangkai bunga, kelopak, mahkota (korola), korona (Rahayu, Trisnawati \& Qoyim 2007). Pengamatan bagian-bagian bunga dilakukan dengan cara dipisahkan perbagian bunga (korola, korona, kelopak \& tangkai bunga) (Thaithong, Wai \& Sridith 2008; Tungmunnithum, Kidyoo \& Khunwasi 2011). Pengamatan karakteristik tandan bunga (peduncle) dan tangkai bunga (pedicel) dilihat dari panjang, warna dan diameter. Pengamatan mahkota bunga dilihat dari ketebalan, bentuk mahkota, aksesoris tambahan seperti dasi atau garis madu, dan warna korola. Pengamatan karakteristik korona dilihat dari ketebalan dan warna korona, sedangkan kelopak bunga dilihat dari warnanya. Panjang diukur dengan penggaris, sedangkan diameter dan ketebalan diukur dengan jangka sorong. Penentuan warna dilakukan dengan color chart dari buku Munsell Color Chart for Plant Tissues (2011).

\section{Analisis Data}

Data yang didapatkan dari penelitian ini dianalisis dengan metode deskriptif yaitu membuat deskripsi secara detail dan sistematis tentang karakteristik morfologi beberapa varietas $H$. coronaria dari kawasan hutan kerangas Air Anyir, Bangka. Menurut Sugiyono (2008) metode deskriptif digunakan untuk menganalisis data dengan cara mendeskripsikan atau menggambarkan data yang telah terkumpul sebagaimana adanya tanpa bermaksud membuat kesimpulan yang berlaku untuk umum atau generalisasi. Penyajian data berupa gambar, Tabel dan matriks. Analisis data deskriptif dalam penelitian ini dimaksudkan untuk mendapatkan gambaran mengenai karakteristik morfologi beberapa varietas $H$. coronaria dari kawasan hutan kerangas Air Anyir, Bangka.

Analisis pengelompokkan dengan klastering (Dendrogram). Karakter yang didapat diberi nilai (score), hal ini dimaksudkan untuk dilakukan penentuan karakter apa saja yang akan digunakan sebagai komponen pembanding dalam analisis kekerabatan. Setelah itu, dilakukan pengolahan data. Data yang diperoleh dari hasil penelitian akan diolah dan dianalisis dengan menggunakan SPSS 17 untuk mengetahui tingkat hubungan kekerabatan antar sampel yang didapat dan dilakukan analisis dengan hierarchial cluster.

\section{HASIL DAN PEMBAHASAN}

Varietas yang diperoleh pada survei pendahuluan di kawasan hutan kerangas Air Anyir, Bangka diperkirakan sebanyak 15-20 varietas, sedangkan pada saat penelitian ditempat yang sama ada 6 varietas $H$. coronaria yang berhasil dikarakterisasi. Hal ini disebabkan karena ketika masuk penelitian terdapat berbagai kendala teknis yang terjadi di habitat asli $H$. coronaria sehingga dilakukan pemindahan penanaman $H$. coronaria ke rumah 
percobaan. Kawasan hutan kerangas Air Anyir, Bangka tersebut berdasarkan Perda Kabupaten Bangka No. 1 Tahun 2013 merupakan kawasan peruntukan industri yang menyebabkan alih fungsi-lahan, aktivitas pembukaan lahan dan pengrusakan habitat, sehingga pengamatan karakteristik dilakukan lebih lanjut dirumah percobaan. Berikut gambar beberapa varietas $H$. coronaria yang berhasil dikarakterisasi (Gambar 1).

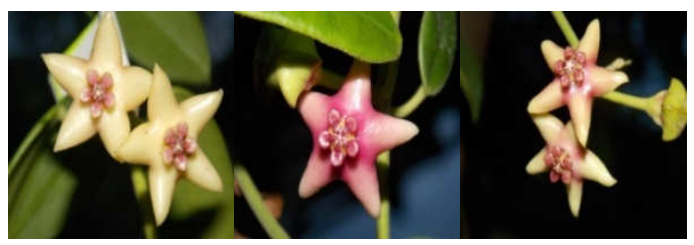

Gambar 1. Beberapa varietas H. coronaria dari kawasan hutan kerangas Air Anyir, Bangka (Dokumentasi Pribadi 2015)

Berdasarkan hasil pengamatan diketahui bahwa secara umum $H$. coronaria merupakan tumbuhan merambat, biasanya melilit pada pohon tumpangan, memiliki variasi warna bunga yang beragam, getah berwarna putih, umumnya batang berbentuk silinder berlekuk (diameter 0,1-0,8 cm), daun majemuk menyirip dengan tata letak daun sejajar (bangun daun telur, ujung daun runcing, pangkal daun tumpul, dan tepi daun rata), daun umumnya berbentuk memanjang (lanset) beberapa berbentuk bulat telur (tebal 0,05-0,15 cm), merupakan bunga majemuk tak berbatas (racemosa), panjang tangkai bunga 1-2 cm, beberapa memiliki aksesoris tambahan yaitu dasi/garis madu. Menurut Rahayu (2006) H. coronaria merupakan tumbuhan epifit merambat, bergetah putih, bunga (panjang tangkai $1-4 \mathrm{~cm}$, diameter $4 \mathrm{~mm}$ ); batang (panjang > $5 \mathrm{~m}$, diameter 4 $\mathrm{mm}$ ); daun (panjang 5-6 cm, lebar $3 \mathrm{~cm}$, pangkal membundar, ujung melancip); (mahkota tambahan berujung tumpul, berwarna krem, diameter $1 \mathrm{~cm}$ ).

\section{Karakteristik 6 Varietas Hoya coronaria}

Terdapat 6 varietas $H$. coronaria yang berhasil dikarakterisasi dengan penciri utama warna bunga, yaitu (1) korola kuning dengan korona pink; (2) korola kuning dengan korona putih; (3) korola kuning bergaris madu pink dengan korona pink; (4) korola pink bergaris madu pink dengan korona pink; (5) korola pink bergaris madu pink dengan korona putih; (6) dan korola putih dengan korona putih.

Varietas 1. Batang berwarna hijau kuning lembut (5 gy 4/6) pada bagian pangkal dan ujung, diameter berkisar 0,17-0,50 $\mathrm{cm}$ dengan bentuk batang silinder besar. Warna daun bagian pangkal hijau kuning lembut (2,5 gy $7 / 6)$, bagian tengah hijau kuning gelap $(2,5$ gy $5 / 4)$ dan bagian ujung hijau kuning terang $(2,5$ gy 5/6), panjang tangkai daun berkisar 0,9-1,5 $\mathrm{cm}$ dengan tebal daun berkisar $0,14 \mathrm{~cm}$, daun berbentuk lanset. Kuntum bunga memiliki warna permukaan atas korola kuning terang (5 y 8/10) dan bawah kuning (5 y 8/8), tidak memiliki garis madu (polos), tebal korola 0,89 $\mathrm{cm}$, korola berbentuk kubah melekuk keluar, memiliki korona berwarna pink keungu-unguan gelap (5 rp 6/6), tebal korona $0,12 \mathrm{~cm}$, dan kelopak bunga berwarna kuning (5 y 8/8). Ibu tangkai (pedankel) berwarna hijau kuning lembut (2,5 gy 7/6), memiliki panjang $2,8 \mathrm{~cm}$, diameter $0,48 \mathrm{~cm}$, dan anak tangkai (pedisel) berwarna kuning (5 gy 7/6), panjang pedisel 1 $\mathrm{cm}$, diameter pangkal $0,21 \mathrm{~cm}$ dan ujung pedisel $0,19 \mathrm{~cm}$.

Varietas 2. Batang berwarna hijau kuning lembut $(2,5$ gy 5/6) pada bagian pangkal dan kuning (5 y 8/8) pada bagian ujung, diameter berkisar 0,16-0,50 $\mathrm{cm}$ dengan bentuk batang silinder pipih. Warna daun bagian pangkal dan tengah sama yaitu hijau kuning terang (5 gy 6/10) dan ujung hijau kuning lembut (2,5 gy 5/6), panjang tangkai daun berkisar $1,5-2 \mathrm{~cm}$ dengan tebal daun berkisar $0,07 \mathrm{~cm}$, daun berbentuk lanset. Kuntum bunga memiliki warna permukaan atas korola putih krem $(2,5 \mathrm{y}$ 8/4) dan bawah kuning (5 y 8/6), tidak memiliki garis madu (polos), tebal korola $0,76 \mathrm{~cm}$, korola berbentuk kubah melekuk kedalam, memiliki korona berwarna kuning pucat (5 y 8/4), tebal 
korona $0,11 \mathrm{~cm}$, dan kelopak bunga berwarna kuning (5 y 8/8). Pedankel berwarna hijau kuning terang $(2,5$ gy $5 / 6)$, memiliki panjang $1,5 \mathrm{~cm}$, diameter $0,27 \mathrm{~cm}$, dan pedisel berwarna merah (5 $\mathrm{r} 4 / 8)$, panjang pedisel $1,7 \mathrm{~cm}$, diameter pangkal $0,20 \mathrm{~cm}$ dan ujung pedisel $0,19 \mathrm{~cm}$.

Varietas 3. Batang berwarna batang hijau zaitun (5 gy 4/8) pada bagian pangkal dan hijau kuning terang $(2,5$ gy $6 / 4)$ pada bagian ujung, diameter berkisar $0,17-0,87 \mathrm{~cm}$, dengan bentuk batang silinder besar. Warna daun bagian pangkal dan tengah sama yaitu hijau kuning lembut (5 gy 4/6) dan ujung hijau kuning gelap (5 gy 6/10), panjang tangkai daun berkisar 1,2$1,4 \mathrm{~cm}$ dengan tebal daun berkisar $0,11 \mathrm{~cm}$, daun berbentuk lanset. Kuntum bunga memiliki warna permukaan atas korola hijau kuning brilian (2,5 gy 8/8) dan bawah hijau kuning terang $(2,5$ gy $7 / 10)$, garis madu berwarna merah lembut $(2,5 \mathrm{r} \mathrm{5/8)}$, tebal korola $0,07 \mathrm{~cm}$, korola berbentuk kubah melekuk keluar, memiliki korona berwarna merah $(5 \mathrm{r} 4 / 6)$, tebal korona $0,13 \mathrm{~cm}$, dan kelopak bunga berwarna hijau kuning cerah (2,5 gy 8/6). Pedankel berwarna hijau kuning terang (2,5 gy 6/8), memiliki panjang $1,2 \mathrm{~cm}$, diameter $0,35 \mathrm{~cm}$, dan pedisel berwarna hijau kuning lembut $(2,5$ gy 6/6), panjang pedisel $1,3 \mathrm{~cm}$, diameter pangkal $0,19 \mathrm{~cm}$ dan ujung pedisel $0,16 \mathrm{~cm}$.

Varietas 4. Batang berwarna hijau kuning gelap $(2,5$ gy 5/4) pada bagian pangkal, hijau kuning lembut (5 gy 6/6) pada bagian ujung, diameter berkisar 0,26-0,36 cm, dengan bentuk batang silinder besar. Warna daun bagian pangkal hijau zaitun (7,5 gy 4/6), bagian tengah dan ujung sama yaitu hijau kuning terang ( 5 gy 4/6), panjang tangkai daun berkisar 1,8-2,2 cm, tebal daun berkisar $0,17 \mathrm{~cm}$, daun berbentuk bulat pendek. Kuntum bunga memiliki permukaan atas pink gelap $(2,5 \mathrm{r}$ 6/6) dan bawah hijau kuning cerah $(2,5$ gy $8 / 6)$, garis madu berwarna merah lembut (2,5 $\mathrm{r} 4 / 8)$, tebal korola $0,06 \mathrm{~cm}$, korola berbentuk kubah melekuk keluar, memiliki korona berwarna merah $(2,5 \mathrm{r} \mathrm{4/8})$, tebal korona $0,14 \mathrm{~cm}$, dan kelopak bunga berwarna hijau kuning cerah (2,5 gy 8/6). Pedankel berwarna hijau kuning terang $(2,5$ gy $5 / 6)$, memiliki panjang $2,8 \mathrm{~cm}$, diameter $0,27 \mathrm{~cm}$, dan pedisel berwarna hijau kuning lembut (2,5 gy 7/6), panjang pedisel 2,3 $\mathrm{cm}$, diameter pangkal $0,18 \mathrm{~cm}$ dan ujung pedisel $0,24 \mathrm{~cm}$.

Varietas 5. Batang berwarna hijau kuning lembut (5 gy 4/6) pada bagian pangkal dan ujung, diameter berkisar 0,17-0,34 cm, dengan bentuk batang silinder besar. Warna daun bagian pangkal hijau kuning lembut (7,5 gy $3 / 4)$, tengah hijau zaitun (7,5 gy 4/6) dan ujung hijau kuning gelap (5 gy 7/8), panjang tangkai daun berkisar 1-1,4 cm, tebal daun berkisar 0,16 $\mathrm{cm}$, daun berbentuk bulat pendek. Kuntum bunga memiliki warna permukaan atas korola merah keabu-abuan cerah $(2,5 \mathrm{r}$ 6/4) dan bawah hijau kuning cerah (2,5 gy 8/4), garis madu berwarna merah keungu-unguan lembut (5 rp $5 / 10$ ), tebal korola $0,88 \mathrm{~cm}$, korola berbentuk kubah melekuk kedalam, memiliki korona berwarna kuning pucat ( 5 y 8/4), tebal korona $0,12 \mathrm{~cm}$, dan kelopak bunga berwarna hijau kuning cerah (2,5 gy 8/6). Pedankel berwarna hijau kuning lembut (5 gy 5/8), memiliki panjang $0,2 \mathrm{~cm}$, diameter $0,32 \mathrm{~cm}$, dan pedisel berwarna hijau kuning lembut (2,5 gy $7 / 6)$, memiliki panjang pedisel $1,3 \mathrm{~cm}$, diameter pangkal $0,18 \mathrm{~cm}$ dan ujung pedisel $0,20 \mathrm{~cm}$.

Varietas 6. Batang berwarna hijau kuning terang (2,5 gy 6/8) pada bagian pangkal dan hijau zaitun (5 gy 4/6) pada bagian ujung, diameter berkisar 0,24-0,40 cm, dengan bentuk batang silinder pipih. Warna daun bagian pangkal hijau kuning terang (5 gy 5/8), tengah hijau kuning lembut (7,5 gy 4/4), dan ujung hijau zaitun (5 gy 4/6), panjang tangkai daun berkisar 0,7-2 cm, tebal daun berkisar 0,09 $\mathrm{cm}$, dengan bentuk daun lonjong lebar. Kuntum bunga memiliki warna permukaan atas hijau kuning pucat $(2,5$ gy 8/2) dan bawah hijau kuning cerah $(2,5$ gy $8 / 4)$, tidak memiliki garis madu (polos), tebal korola 0,07 cm, korola berbentuk kubah dengan lekukan korola lebih kedalam, memiliki korona berwarna hijau kuning lembut (2,5 gy 8/4), tebal korona 0,14 $\mathrm{cm}$, dan kelopak bunga berwarna hijau kuning lembut $(2,5$ gy $7 / 6)$. Pedankel berwarna hijau kuning brilian (2,5 gy 8/8), memiliki panjang $0,6 \mathrm{~cm}$, diameter $0,41 \mathrm{~cm}$, dan pedisel berwarna hijau kuning lembut (2,5 gy 7/6), memiliki panjang pedisel $1,2 \mathrm{~cm}$, diameter pangkal 0,19 $\mathrm{cm}$ dan ujung pedisel $0,22 \mathrm{~cm}$. 


\section{Analisis Karakteristik Morfologi coronaria}

Hasil pengamatan menunjukkan bahwa beberapa varietas $H$. coronaria memiliki karakteristik daun, batang, bunga, dan tangkai bunga yang berbeda. Perbedaan karakteristik yang paling menonjol adalah bentuk dan warna bunga. Variasi warna bunga $H$. coronaria yang diperoleh yaitu korola kuning dengan korona pink; korola kuning dengan korona putih; korola kuning bergaris madu pink dengan korona pink; korola pink bergaris madu pink dengan korona pink; korola pink bergaris madu pink dengan korona putih; dan korola putih dengan korona putih. Dilihat dari warna korola, dapat dikelompokkan bahwa varietas 1, 2 dan 3
H. memiliki warna korola kuning, varietas 4 dan 5 memiliki warna korola pink dan varietas 6 memiliki warna korola putih. Berdasarkan warna korona, dapat dikelompokkan bahwa varietas 1, 3 dan 4 memiliki korona pink dan varietas 2, 5 dan 6 memiliki korona putih. Berdasarkan bentuk korola, dapat dikelompokkan bahwa varietas 1,4 dan 5 memiliki bentuk korola melekuk keluar, varietas 2 dan 3 memiliki bentuk korola melekuk kedalam, dan varietas 6 memiliki bentuk korola lebih melekuk kedalam. Berikut gambar beberapa variasi warna $H$. coronaria dari kawasan hutan kerangas Air Anyir, Bangka.

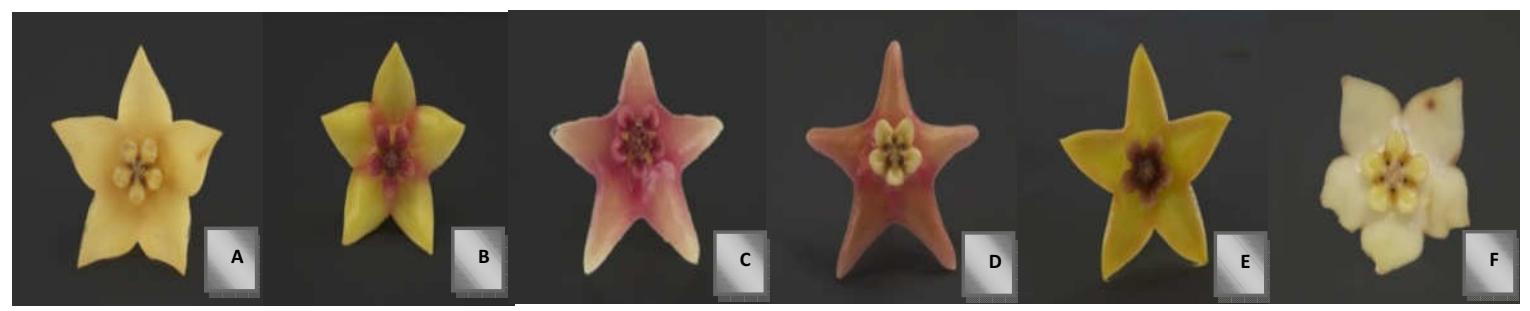

Gambar 2. Morfologi bunga $H$. coronaria dengan variasi warna yang berbeda. (A) varietas 1 , (B) varietas $2,(\mathrm{C})$ varietas 3, (D) varietas 4, (E) varietas 5, (F) varietas 6.

Berdasarkan hasil tersebut diketahui bahwa terdapat perbedaan warna bunga pada masingmasing varietas yang meliputi warna permukaan korola atas, permukaan korola bawah, korona, garis madu, dan kelopak bunga. Menurut Henuhili (2007) warna bunga dibedakan menjadi 3 kelompok utama, yaitu: putih, kuning, merah dan biru. Bahan yang bertanggung jawab terhadap warna bunga adalah antosianin, antosantin dan pigmen plastid. Antosianin menentukan warna merah, merah tua, biru dan merah kebiruan. Antosantin menentukan warna kuning gading sampai kuning tua. Pigmen plastid menetukan warna yang bervariasi dari kuning sampai oranye atau merah dan dapat memberikan warna yang sama dengan yang diberikan oleh antosantin (Lenz \& Wimber 1959 dalam Henuhili 2007).

Berdasarkan penelitian yang dilakukan dapat diketahui bahwa beberapa varietas $H$. coronaria memiliki perbedaan karakteristik daun, batang, bunga, dan tangkai bunga. Dilihat dari perbedaan bentuk dan warna daun, diketahui bahwa daun $H$. coronaria dengan variasi warna kuning (varietas 1 , varietas 2 dan varietas 3) memiliki daun lanset berwarna hijau kuning, variasi warna merah (varietas 4 dan varietas 5) memiliki daun bulat pendek berwarna hijau kuning dan variasi warna putih (varietas 6) memiliki daun lebih besar dengan bentuk lonjong lebar dan berwarna hijau gelap. Selain karakteristik warna dan bentuk daun yang berbeda, berdasarkan hasil yang didapat menunjukkan bahwa tangkai daun setiap varietas $H$. coronaria memiliki panjang tangkai yang berbeda. Hal ini diperkuat oleh pernyataan Tjitrosoepomo (1985) yang menyatakan bahwa bentuk dan ukuran tangkai daun sangat berbeda-beda menurut jenis tumbuhan, bahkan pada satu tumbuhan ukuran dan bentuknya dapat berbeda-beda. Berikut gambar daun beberapa varietas $H$. coronaria. 

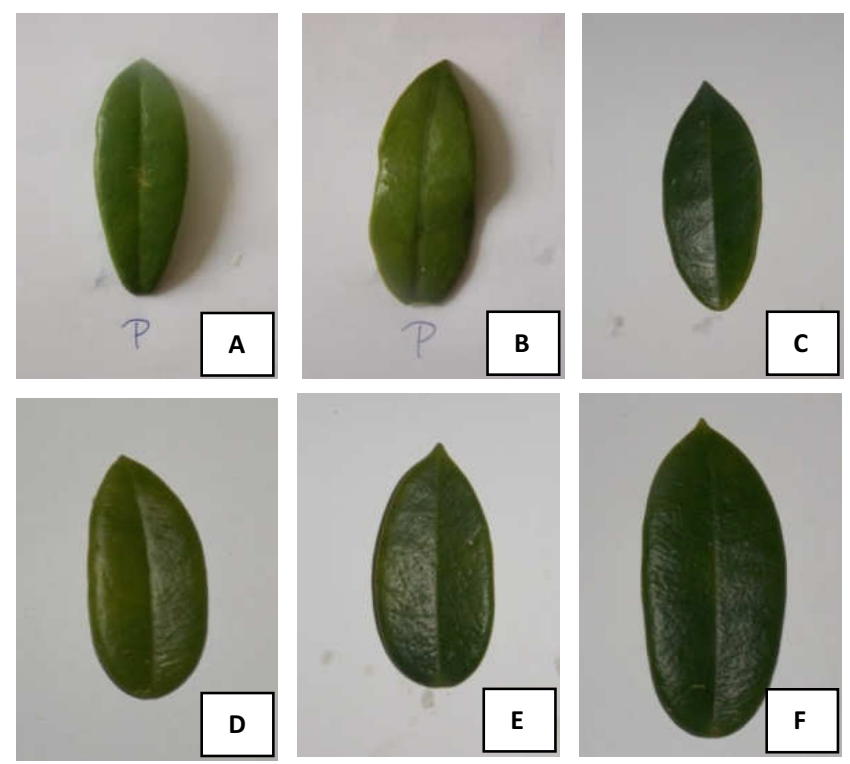

Gambar 3. Morfologi daun beberapa varietas $H$. coronaria. (A) varietas 1, (B) varietas 2, (C) varietas 3 (D) verietas 4, (E) verietas 5, (F) varietas 6.

Perbedaan karakteristik lainnya adalah bentuk dan warna batang $H$. coronaria. Pada umumnya, arah tumbuh batang $H$. coronaria menuju cahaya, dimana batangnya sendiri naik dan melilit penunjangnya. Dilihat dari bentuk dan warna batang, dapat dikelompokan bahwa varietas 1 dan 3 memilki warna batang hijau kuning muda dengan batang silinder besar, varietas 2 memiliki warna batang hijau gelap dengan batang silinder pipih, varietas 4 dan 5 memiliki warna batang hijau lembut dengan batang silinder besar sedangkan varietas 6 memiliki warna batang hijau kuning gelap dengan batang silinder pipih.
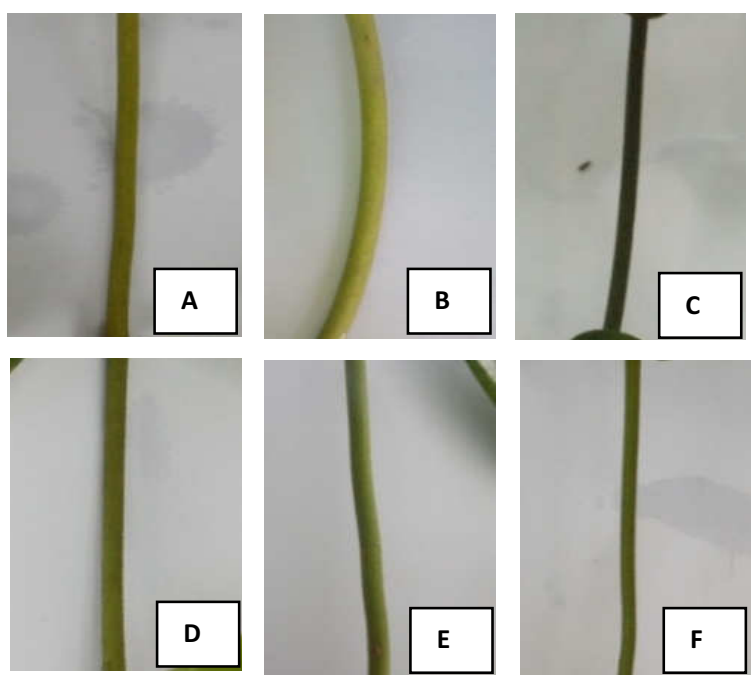

Gambar 4. Morfologi batang beberapa varietas $H$. coronaria. (A) varietas 1, (B) varietas 2, (C) varietas 3 , (D) varietas 4, (E) varietas 5, (F) varietas 6. 


\section{Analisis Kekerabatan beberapa Varietas $\boldsymbol{H}$. coronaria}

Analisis kekerabatan yang dilakukan pada 6 varietas $H$. coronaria berdasarkan karakter morfologinya, diperoleh hasil berupa dendrogram sebagai berikut:

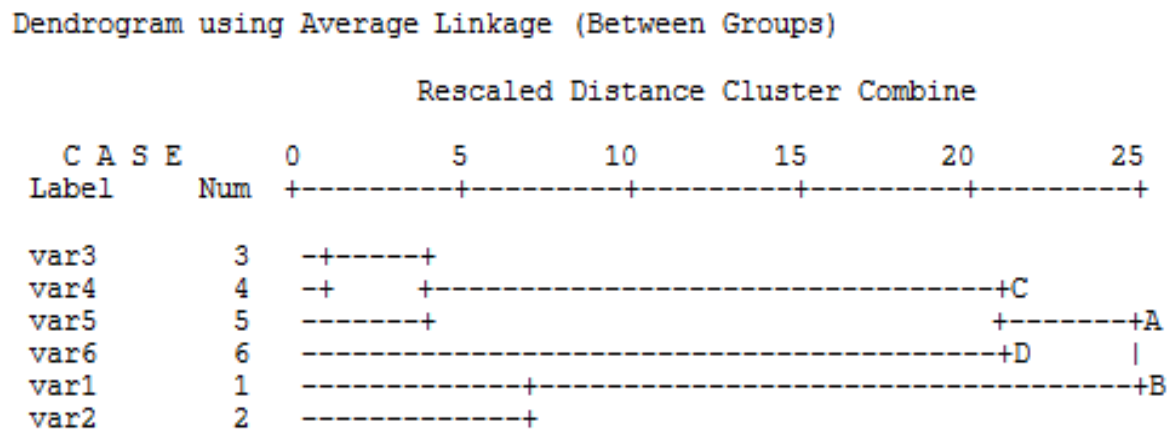

Gambar 5. Dendrogram hubungan kekerabatan antara 6 varietas $H$. coronaria

Berdasarkan dendrogram pada gambar 5, terdapat dua cluster kelompok besar berdasarkan karakter morfologinya. Dua kelompok ini ditandai dengan huruf $\mathrm{A}$ dan $\mathrm{B}$. Hasil analisis yang digambarkan dalam dendrogram tersebut menunjukkan pengelompokkan dan kekerabatan dari 6 varietas $H$. coronaria. Kelompok pertama beranggotakan var3, var4, var5, dan var6, sedangkan kelompok kedua beranggotakan var1 dan var2. Pengelompokkan ini berdasarkan perbedaan karakter yang memisahkan kelompok A dan B yaitu warna korola bawah, warna kelopak bunga dan diameter pedankel. Kelompok A memiliki warna korola bawah kuning, sedangkan kelompok B memiliki warna korola bawah hijau kuning. Warna kelopak bunga pada kelompok A kuning dan kelompok B berwarna hijau kuning, selain itu kelompok A memiliki diameter pangkal pedisel $0,1-0,2 \mathrm{~cm}$ dan kelompok B memiliki diameter pangkal pedisel $0,2-0,3 \mathrm{~cm}$. Persamaan karakter yang dimiliki kelompok A dan B adalah tebal korona dan warna pedisel, dimana tebal koronanya > $0,1 \mathrm{~cm}$ dan warna pediselnya yaitu kuning.

Selanjutnya kelompok A memisah menjadi 2 kelompok, yaitu kelompok C dan D. Kelompok C beranggotakan var3, var4 dan var5, sedangkan kelompok $\mathrm{D}$ beranggotakan var6. Memisahnya kelompok A menjadi kelompok $\mathrm{C}$ dan $\mathrm{D}$ dikarenakan terdapatnya beberapa perbedaan karakter yang lebih spesifik pada kelompok $\mathrm{C}$ dan $\mathrm{D}$ yaitu warna ujung batang, bentuk batang, warna ujung daun, panjang tangkai daun, tebal daun, dan ada tidaknya garis madu. Pada kelompok C memiliki warna ujung batang hijau kuning, sedangkan kelompok D memiliki warna ujung batang hijau. Bentuk batang pada kelompok C silinder besar dan kelompok D berbentuk silinder pipih, kemudian warna ujung daun kelompok C hijau kuning dan kelompok D berwarna hijau. Pada kelompok $\mathrm{C}$ memiliki panjang tangkai daun 1-3 cm dan kelompok D memiliki panjang tangkai daun $0,5-2 \mathrm{~cm}$, kemudian kelompok $\mathrm{C}$ memiliki tebal daun < $0,1 \mathrm{~cm}$ dan kelompok D memiliki tebal daun > $0,1 \mathrm{~cm}$. Selain itu juga, kelompok $\mathrm{C}$ tidak memiliki garis madu dan kelompok D memiliki garis madu.

Berdasarkan hasil analisis klastering, diketahui bahwa var3 dan var4 memiliki jarak cluster paling kecil. Hal ini menunjukkan bahawa var3 dan var4 memiliki tingkat kekerabatan paling dekat. Berdasarkan karakter masing-masing individu menunjukkan bahwa var3 dan var4 memiliki banyak kesamaan karakter dan sedikit perbedaan. Pada var5 jarak cluster yang dimiliki tidak begitu jauh sehingga masih bisa dikelompokkan dalam kekerabatan yang dekat bersama var3 dan var4. Var6 memiliki jarak cluster paling jauh sehingga 
memisah dari var3 dan var4. Var1 dan var2 memiliki kesamaan karakter yang cukup dekat, namun cukup jauh dari var lainnya sehingga dikelompokkan menjadi satu cluster. Menurut Suratman dan Setyawan (2000) hubungan kekerabatan dapat digunakan untuk menduga tingkat kesamaan antar spesies atau populasi. Semakin banyak kesamaan karakter yang dimiliki pada individu yang dibandingkan, maka semakin dekat hubungan kekerabatannya, dan berlaku pula dengan sedikitnya kesamaan karakter yang dimiliki, maka hubungan kekerabatannya semakin jauh. Memisahnya varietas $H$. coronaria menjadi beberapa kelompok pada dendrogram disebabkan karena adanya perbedaan karakteristik yang dimiliki oleh masing-masing individu. Setiap individu baik tingkat spesies maupun varietas pasti memiliki ciri atau sifat khusus yang tidak dimiliki oleh individu lain.

\section{KESIMPULAN}

Enam varietas $H$. coronaria asal hutan kerangas Air Anyir, Bangka masing-masing memiliki perbedaan karakteristik pada daun, batang, bunga, dan tangkai bunga. Pengelompokkan secara dikotomi berdasarkan persamaan beberapa karakter pada keenam varietas tersebut tidak ada konsistensi, sehingga keenam varietas tersebut masing-masing dianggap berbeda. Analisis klastering berdasarkan karakter morfolofi pada keenam varietas menghasilkan dua kelompok yaitu kelompok pertama (A) beranggotakan var3, var4, var5, dan var6, sedangkan kelompok kedua (B) beranggotakan var1 dan var2. Kelompok A memisah kembali menjadi dua kelompok, yaitu kelompok C dan D. Kelompok C beranggotakan var3, var4 dan var5, sedangkan kelompok D beranggotakan var6.

\section{DAFTAR PUSTAKA}

Henuhili V. 2007. Pewarisan Warna Bunga pada Anggrek. Seminar Nasional MIPA. Yogyakarta.
Kabupaten Bangka. 2013. Peraturan Daerah Nol Tahun 2013 Tentang Rencana Tata Ruang Wilayah Kabupaten Bangka Tahun 2010-2030. BAPEDA: Bangka.

[Kemenhut] Kementerian Kehutanan. 2012. Profil Kehutanan 33 Provinsi. Jakarta: Biro Perencanaan Sekretariat Jendral.

[Kemenhut] Kementerian Kehutanan. 2014. Statistik Kementrian Kehutanan Tahun 2013. Jakarta: Biro Perencanaan Sekretariat Jendral.

Kissinger, Zuhud EA, Darusman LK, Siregar IZ. 2013. Keanekaragaman Tumbuhan Obat dari Hutan Kerangas. Bogor. J Hutan Tropis. 1 (1): 2-3.

Kusuma et al. 2013. Ekologi Hutan. Institut Pertanian Bogor, Bogor.

Rahayu S. 2012. Potensi dan Konservasi JenisJenis Hoya Dataran Tinggi Pulau Jawa. Bogor. J Berkala Penelitian Hayati. 18: 1-7.

Rahayu S, Trisnawati DE, Qoyim I. 2007. Biologi Bunga Picis Kecil (Hoya lacunosa B1.) di Kebun Raya Bogor. J Biodiversitas. 8 (1): 7-11.

Sugiyono. 2008. Metode Penelitian Bisnis. Alfabeta, Bandung.

Suratman DP dan Setyawan AD. 2000. Analisis Keragaman Genus Ipomomea Berdasarkan Karakter Morfologi. J Biodiversitas. 1(2): 72-79.

Thaithong O, Wai JS and Sridith K. 2008. Hoya imperialis Lindl. (Apocynaceae: Asclepiadoideae), a New Record for Thailand. J Thailand Forum Bulletin. 36: 81-85.

Tjitrosoepomo G. 1985. Morfologi Tumbuhan. Gadjah Mada University Press, Yogyakarta.

Tungmunnithum D, Kidyoo M and Khunwasi C. 2011. Morphological Variations in Hoya siamica Craib (Asclepiadaceae) in Thailand. J Tropical Natural History. 11: 5-9. 